\title{
Seed treatment, soil compaction and nitrogen management affect upland rice ${ }^{1}$
}

\author{
Veneraldo Pinheiro², Adriano Stephan Nascente ${ }^{2}$, Luis Fernando Stone², Mabio Chrisley Lacerda²
}

\section{ABSTRACT}

Water availability for cultivation of irrigated rice (Oryza sativa L.) is decreasing worldwide. Therefore, new technologies are needed to grow rice under aerobic conditions, in order to produce rice grains without yield losses and with lower water consumption. This study aimed at determining the best combination of management options for producing upland rice. A randomized blocks design, in a factorial scheme, was used. The treatments consisted of a combination of five rice cultivars (BRS Caçula, BRS Serra Dourada, BRS Primavera, BRS Sertaneja and BRS Esmeralda) with two compaction pressures in the seed furrow $(25 \mathrm{kPa}$ or $126 \mathrm{kPa}$ ), two types of seed treatment (with or without pesticide) and two types of $\mathrm{N}$ management (all at sowing or all at topdressing). Applying $\mathrm{N}$ at sowing instead of at topdressing produced higher grain yield in the no-tillage system (NTS). Under this system, upland rice genotypes show higher grain yield with higher compaction pressure. Seed treatment with pesticide provided greater grain yield for the BRS Sertaneja, in NTS, and for all genotypes in the conventional tillage system (CTS). BRS Esmeralda, in NTS, and BRS Esmeralda and BRS Primavera, in CTS, were the most productive genotypes. Moreover, in NTS, the application of $\mathrm{N}$ at sowing and the compaction pressure on the seed furrow are important for increasing upland rice grain yield. In CTS, seed treatment is important to improve upland rice grain yield.

KEY-WORDS: Termite; pesticide; fipronil; aerobic rice.

\section{INTRODUCTION}

Rice is included in the diet of half the world population. Most of this cereal grain is grown on irrigated land (Nayar 2014). However, available water for growing flood-irrigated rice has declined. As a result, researchers are looking for alternatives with greater water use efficiency (Farooq et al. 2009,

\section{RESUMO}

Tratamento de sementes, compactação do solo e manejo de nitrogênio afetam o arroz de terras altas

A disponibilidade de água para o cultivo de arroz irrigado (Oryza sativa L.) está reduzindo-se em todo o mundo. Portanto, faz-se necessário desenvolver tecnologias que permitam o cultivo de arroz em condições aeróbicas, para produzir grãos de arroz sem perdas de rendimento e obter maior eficiência no uso da água. Objetivouse determinar a melhor combinação de opções de manejo para a produção de arroz de terras altas. O delineamento experimental foi em blocos casualizados, em esquema fatorial. Os tratamentos consistiram da combinação de cinco cultivares de arroz (BRS Caçula, BRS Serra Dourada, BRS Primavera, BRS Sertaneja e BRS Esmeralda) com duas pressões de compactação no sulco de semeadura (25 kPa ou $126 \mathrm{kPa}$ ), dois tipos de tratamento de sementes (com ou sem pesticida) e dois tipos de manejo de $\mathrm{N}$ (todo o $\mathrm{N}$ na semeadura ou todo o $\mathrm{N}$ em cobertura). A aplicação de todo o $\mathrm{N}$ na semeadura, ao invés do $\mathrm{N}$ em cobertura, foi eficaz para proporcionar maior produção de grãos no sistema plantio direto (SPD). Nesse sistema, genótipos de arroz de terras altas apresentam melhores resultados com maior pressão de compactação. O tratamento de sementes com inseticida proporcionou maior rendimento de grãos da BRS Sertaneja, no SPD, e para todos os genótipos no sistema plantio convencional (SPC). ABRS Esmeralda, no SPD, e BRS Esmeralda e BRS Primavera, no SPC, foram os genótipos mais produtivos. Além disso, no SPD, a aplicação de N na semeadura e a pressão de compactação sobre o sulco de semeadura são importantes para aumentar a produtividade de grãos de arroz de terras altas. No SPC, o tratamento de sementes é importante para melhorar o rendimento de grãos do arroz de terras altas.

PALAVRAS-CHAVE: Cupim; pesticida; fipronil; arroz aeróbico.

Prasad 2011), including growing rice under upland conditions, such as under the no-tillage system (NTS) (Nascente et al. 2013a).

According to Nokkoul \& Wichitparp (2014), 20 million hectares of upland rice are cultivated per year, primarily in Latin America and Africa. However, in these regions, drought and low technology (restricted use of seeds and fertilization 
and limited control of weeds, insects and diseases) result in low grain yield (Dobermann \& Fairhurst 2000).

In Brazil, upland rice is mainly cultivated when new areas are open for agriculture or in pasture renovation. In both cases, the conventional tillage system (CTS) is generally used (Santos et al. 2006). This system has provided higher yield than NTS (Kluthcouski et al. 2000, Nascente et al. 2011, Nokkoul \& Wichitparp 2014), maybe due to the demand of rice for soils with high macroporosity. However, this system is not sustainable, as it can cause serious erosion problems.

NTS provides greater benefits to the environment, such as enhanced water conservation, increased soil fertility and organic matter content and better soil protection against erosion (Nascente et al. 2015). Thus, the popularity of NTS has increased worldwide, being used in around 117 million ha (FAOSTAT 2014). In Brazil, NTS is used in approximately 30 million of the 50 million ha of agricultural land (Nascente \& Crusciol 2012).

NTS facilitates crop rotation with soybean and corn (Nascente et al. 2011), but upland rice does not show good development or yield under this system (Olofintoye \& Mabbayad 1980, Kluthcouski et al. 2000, Nascente et al. 2011, Nascente et al. 2013b). Therefore, it is important to develop technologies to improve rice grain yield under NTS, aimed at sustainable agriculture, higher food production and water conservation (Farooq et al. 2009).

In NTS, the 0-0.05 m depth soil layer usually has high porosity, because of the action of seeder discs, higher concentration of roots and organic matter, greater biological activity and more soil wetting and drying cycles (Silva 2003, Aranda et al. 2011). High soil porosity can hinder the contact of rice seeds with soil and reduce plant emergence. Compaction in the seed furrow improves soil-seed contact, allowing the latter to absorb water and germinate (Silva 2006). The use of compaction increases plant stand and yield by $40 \%$ and $15 \%$, respectively, in lowland rice (Soares \& Carrão 1993), and 17 \% for yield in upland rice using NTS (Portugal et al. 2013).

Termites (Proconitermes spp. and Syntermes molestus) are another problem that can decrease rice grain yield in NTS. These insects occur in most Brazilian Savannah rice fields, causing significant losses in grain yield, and are the main reason for using insecticide to treat seeds before sowing (Ferreira et al. 2007). Compaction in the seed furrow also helps to minimize the damage caused by these termites. Barrigossi et al. (2011) observed that termite attacks on upland rice grown under NTS were lower with compaction in the seed furrow, and reported that the benefits of this technique are reinforced when combined with insecticide seed treatment.

According to Radford \& Allsopp (1987), soil compaction with a press wheel improves the soilwater supply and reduces lethal damage to seeds and seedlings caused by a wide range of insect species. Compacting the row may squash large insect pests near the seed, killing or injuring them; restrict insect movement through the soil; and improve soil water supply, enabling seedlings to avoid pest damage by faster germination and growth or by decreasing soil porosity, reducing carbon dioxide diffusion from the seed/seedling. These authors also reported that the use of insecticides in conjunction with press wheels enhanced seedlings establishment, in some situations.

Upland rice genotypes produce different grain yield, according to soil tillage (Moura Neto et al. 2002, Guimarães et al. 2006, Reis et al. 2008, Nascente et al. 2011). Nascente et al. (2011) assessed eight upland rice cultivars and observed that, despite the higher average yield obtained under CTS $\left(4,349 \mathrm{~kg} \mathrm{ha}^{-1}\right)$, when compared to NTS $\left(3,521 \mathrm{~kg} \mathrm{ha}^{-1}\right)$, the Caiapó genotype exhibited similar yield in both systems. Nascente et al. (2013b) evaluated five genotypes at another site, and found that the grain yield of the BRS Primavera genotype did not differ between NTS $\left(3,559 \mathrm{~kg} \mathrm{ha}^{-1}\right)$ and CTS $\left(3,644 \mathrm{~kg} \mathrm{ha}^{-1}\right)$, but noticed that other genotypes yielded more under CTS. These studies reinforce the need to identify genotypes more adapted to each system. The choice of the cultivar is a determining factor in successful rice production under NTS.

In NTS, greater N immobilization can occur due to the presence of straw on the soil surface, which, in turn, reflects on the availability of this nutrient for subsequent crops (Nascente \& Crusciol 2013, Nascente et al. 2013a). Thus, under NTS, it is important to apply a higher amount of $\mathrm{N}$ at sowing, if compared to CTS (Fageria 2014). Nascente et al. (2011) reported that rice growing under NTS achieved grain yield similar to that under plowing, when $45 \mathrm{~kg} \mathrm{ha}^{-1}$ of $\mathrm{N}$ were applied one day before sowing. On the other hand, when $\mathrm{N}$ was applied at topdressing (45 days after rice sowing, at the tillering stage), the rice yield under NTS was lower than that under CTS. 
This study aimed at determining the best combination of management options for upland rice production, concerning seed treatment, $\mathrm{N}$ management and soil compaction in the seed furrow, under no-tillage and conventional tillage systems.

\section{MATERIAL AND METHODS}

The experiments were conducted in Santo Antônio de Goiás (16²7'28'S, 49 $19^{\circ}$ '52'W and altitude of $823 \mathrm{~m}$ ), Goiás State, Brazil, where the tropical Brazilian Savannah climate is considered Aw, according to the Köppen's classification. There are two distinct seasons: usually dry from May to September (fall/winter) and rainy from October to April (spring/summer). Temperature and rainfall data were recorded during the experiment (Figure 1).

The soil was classified as a kaolinitic, thermic Typic Haplorthox, sandy clay loam (Embrapa 2006). The experimental areas have been under degraded Brachiaria brizantha pasture for 15 years. The soil texture values, in the $0-0.20 \mathrm{~m}$ depth layer, were $605 \mathrm{~g} \mathrm{~kg}^{-1}$ of sand, $95 \mathrm{~g} \mathrm{~kg}^{-1}$ of silt and $300 \mathrm{~g} \mathrm{~kg}^{-1}$ of clay. The soil chemical characteristics were determined before the treatments were applied (Claessen 1997), as it follows: $\mathrm{pH}\left(\mathrm{H}_{2} \mathrm{O}\right)=5.3$; $\mathrm{Ca}^{2+}=7 \mathrm{mmol}_{\mathrm{c}} \mathrm{dm}^{-3} ; \mathrm{Mg}^{2+}=4 \mathrm{mmol}_{\mathrm{c}} \mathrm{dm}^{-3}$; $\mathrm{Al}^{3+}=1 \mathrm{mmol}_{\mathrm{c}} \mathrm{dm}^{-3} ; \mathrm{H}^{+}+\mathrm{Al}^{3+}=12 \mathrm{mmol}_{\mathrm{c}} \mathrm{dm}^{-3} ; \mathrm{P}=$ $0.4 \mathrm{mg} \mathrm{dm}^{-3} ; \mathrm{K}^{+}=78 \mathrm{mg} \mathrm{dm}^{-3} ; \mathrm{Cu}^{2+}=2.3 \mathrm{mg} \mathrm{dm}^{-3}$;
$\mathrm{Zn}^{2+}=1.2 \mathrm{mg} \mathrm{dm}{ }^{-3} ; \mathrm{Fe}^{3+}=35.8 \mathrm{mg} \mathrm{dm}{ }^{-3} ; \mathrm{Mn}^{2+}=$ $34.7 \mathrm{mg} \mathrm{dm}^{-3}$; soil organic matter $=29.9 \mathrm{~g} \mathrm{~kg}^{-1}$.

Two trials were performed: one under a no-tillage system and another using conventional tillage (one plowing and two disking). Experiments were arranged in a randomized complete blocks design, in a $5 \times 2 \times 2 \times 2$ factorial scheme, with three replications, consisting of five upland rice cultivars, two $\mathrm{N}$ managements, two compaction pressures in the seed furrow and two types of seed treatment. The plots measured $16 \mathrm{~m}$ wide (40 rows of rice) $\mathrm{x}$ $12 \mathrm{~m}$ long. The usable area of the plot consisted of 30 central rows of rice, disregarding $0.50 \mathrm{~m}$ on either side.

The upland rice cultivars used were BRS Caçula, BRS Primavera, BRS Serra Dourada, BRS Sertaneja and BRS Esmeralda. Two different N application times ( $45 \mathrm{~kg} \mathrm{ha}^{-1}$ of $\mathrm{N}$, using urea) were compared: day one and 20 days after rice emergence in the tillering stage. $\mathrm{N}$ was applied on the soil surface. Seed treatments were with and without fipronil + pyraclostrobin + thiophanate methyl $(62.5+0.625+50.625 \mathrm{ml}$ a.i. $/ 100 \mathrm{~kg}$ of seeds $)$. The compaction pressures were $25 \mathrm{kPa}$, provided by the original "V" press wheels of the seed drill, and $126 \mathrm{kPa}$, provided by the $635 \mathrm{~kg}$ on the front axle of an MF 52754 x 2 tractor with 7.50-16 bald directional vehicular tires (no "treads", larger contact area), at no additional ballast. The rear tire contact area was

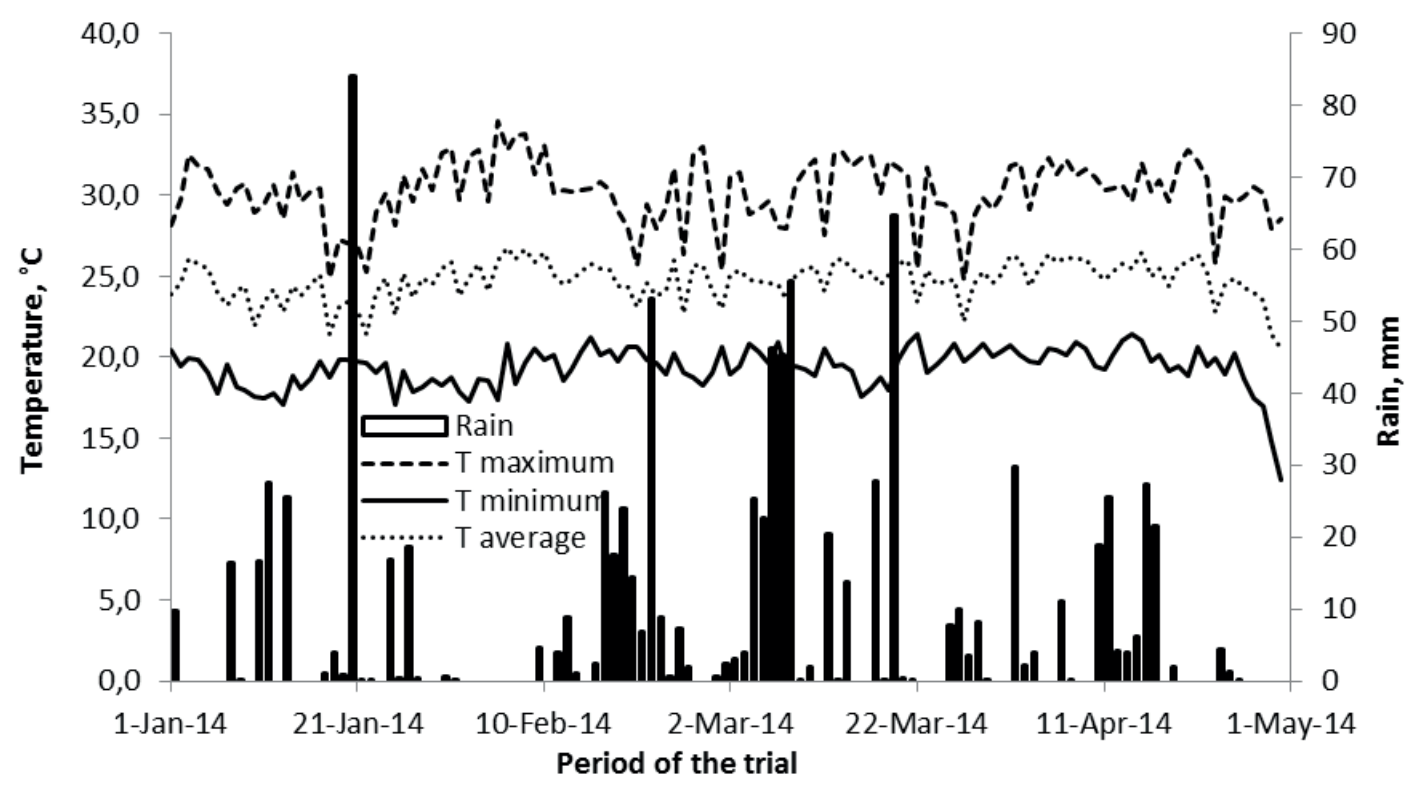

Figure 1. Maximum, minimum and average temperatures $(\mathrm{T})$ and rainfall during the upland rice trial period under no-tillage and conventional tillage. 
increased and its weight reduced to the minimum, in order to decrease its influence on the seed furrow.

Sowing was carried out mechanically, using $70 \mathrm{~kg} \mathrm{ha}^{-1}$ of rice seeds, on January 2 (2014), and rice plants emerged five days later. The row spacing used was $0.40 \mathrm{~m}$, with 90 viable seeds per meter. Fertilization was performed based on the soil analysis, following the recommendations of Sousa \& Lobato (2004), with $15 \mathrm{~kg} \mathrm{ha}^{-1}$ of $\mathrm{N}$ as urea, $90 \mathrm{~kg} \mathrm{ha}^{-1}$ of $\mathrm{P}_{2} \mathrm{O}_{5}$ as triple superphosphate and $45 \mathrm{~kg} \mathrm{ha}^{-1}$ of $\mathrm{K}_{2} \mathrm{O}$ as potassium chloride. Cultural practices were in accordance with standard recommendations for rice crop, in order to keep the area free from weeds, diseases and insects.

Average rice harvest was carried out after physiological maturity (April 26, 2014) by hand, in the usable area of each plot. Plots were evaluated for number of tillers, determined by measuring 10 plants per plot in the full flowering stage; plant height (m), by measuring 10 plants per plot, when the crop was in the phenological stage of pasty grains, and recording the distance between the soil surface and the top end of the highest panicle; number of panicles $\mathrm{m}^{-1}$, determined by counting the number of panicles in a 1.0 linear $\mathrm{m}$ of one of the rows, in the useful area of each plot; spikelet fertility (\%), established by counting the number of filled spikelets in a sample of 100 grains in each plot; 1,000-grain weight, randomly evaluated by collecting and weighing two samples of 1,000 grains from each plot, corrected to $13 \%$ of water content; and grain yield, determined by weighing the grain harvested from each plot, corrected to $13 \%$ of water content and converted to $\mathrm{kg} \mathrm{ha}^{-1}$.

The SAS software (SAS Institute, Cary, NC, USA) was used for statistical analysis. Data from each soil management system were subjected to analysis of variance and, when the F-test was significant, factor means were compared using the Tukey's test $(\mathrm{p}<0.05)$.

\section{RESULTS AND DISCUSSION}

$\mathrm{N}$ management had a marked effect on plant height and grain yield under NTS (Table 1). Thus, $\mathrm{N}$ applied at sowing provided better results than at topdressing. These results could be due to the fact that NTS usually involves straw on the soil surface, and bacteria from the soil use the $\mathrm{N}$ to degrade this straw, what could cause a lack of this nutrient
(Fageria 2014). Bacteria and fungi consume inorganic molecules such as $\mathrm{N}$ and incorporate them into their cells. Therefore, $\mathrm{N}$ does not move easily through the soil and is unavailable to plants (Fageria et al. 2011). It is likely that by applying the total amount of $\mathrm{N}$ at sowing, this shortage of $\mathrm{N}$ was not allowed. On the other hand, when $\mathrm{N}$ was applied at topdressing, there was likely a lack of $\mathrm{N}$ for the rice plants, what significantly affected plant height and grain yield. Nascente et al. (2011) reported that rice growing under NTS achieved grain yield similar to that under plowing, when $45 \mathrm{~kg} \mathrm{ha}^{-1}$ of $\mathrm{N}$ were applied one day before rice planting.

In NTS, the increased compaction pressure (from $25 \mathrm{kPa}$ to $126 \mathrm{kPa}$ ), in turn, increased the grain yield of the upland rice genotypes (Table 1). Chen et al. (2004) studied corn, soybean and wheat sowing, and reported that removing the press wheel reduced the speed of emergence and final stand of these crops.

Based on our results, we can conclude that the genotypes evaluated are sensitive to the higher soil porosity provided by the furrow-opening device, and only compaction performed by the "V" wheel of the seeding machine was not enough to improve soil adherence to the seeds. In order to increase yield, rice must be sown using a seeding machine with a device to provide higher compaction in the seed furrow. In CTS, due to soil preparation, only seeder wheel compression is sufficient to provide adhesion between the soil and rice seeds.

Silva (2006) reported that, under NTS, compaction in the seed furrows provides better contact between the soil and the seed, resulting in earlier water absorption and faster germination. Furthermore, Radford \& Allsopp (1987) reported that soil compaction with a press wheel reduced the lethal damage to seeds and seedlings caused by a wide range of insect species. This information is interesting because, if the producer cannot afford to purchase pesticide, an alternative would be to compact the seed furrow.

Under NTS, the use of seed treatment significantly increased the grain yield of the BRS Sertaneja genotype (Table 2). Based on the results, it can be concluded that the seed treatment was effective in controlling the main rice pests, resulting in increased yield for this genotype. Termite damage is compounded under NTS, because it leads to straw accumulation on the soil surface, increasing the food available to termites, what can cause a total loss 
Table 1. Number of tillers (NT), plant height (PH), number of panicles $\mathrm{m}^{-2}$ (PAN), spikelet fertility (SF), 1,000-grain weight (MGRAIN) and grain yield (YIELD) of upland rice cultivars under no-tillage system, as a function of N management, compaction pressure in the seed furrow and seed treatment with pesticide.

\begin{tabular}{|c|c|c|c|c|c|c|}
\hline Treatment & NT & $\mathrm{PH}$ & PAN & SF & MGRAIN & YIELD \\
\hline N management & $\mathrm{n}^{\mathrm{o}} \mathrm{m}^{-2}$ & $\mathrm{~cm}$ & $\mathrm{n}^{\mathrm{o}} \mathrm{m}^{-2}$ & $\%$ & $\mathrm{~g}$ & $\mathrm{~kg} \mathrm{ha}^{-1}$ \\
\hline 20 days after sowing & $199 \mathrm{a}^{1}$ & $105 \mathrm{~b}$ & $197 \mathrm{a}$ & $88 \mathrm{a}$ & $27.45 \mathrm{a}$ & $3,446 b$ \\
\hline 1 day after sowing & $202 \mathrm{a}$ & $108 \mathrm{a}$ & $201 \mathrm{a}$ & $89 \mathrm{a}$ & $27.37 \mathrm{a}$ & $3,678 \mathrm{a}$ \\
\hline \multicolumn{7}{|l|}{ Compaction pressure } \\
\hline $25 \mathrm{kPa}$ & $196 \mathrm{~b}$ & $105 \mathrm{~b}$ & $195 \mathrm{~b}$ & $88 \mathrm{a}$ & $27.49 \mathrm{a}$ & $3,362 \mathrm{~b}$ \\
\hline $126 \mathrm{kPa}$ & $205 \mathrm{a}$ & $108 \mathrm{a}$ & $204 \mathrm{a}$ & $89 \mathrm{a}$ & $27.33 \mathrm{a}$ & $3,763 \mathrm{a}$ \\
\hline \multicolumn{7}{|l|}{ Seed treatment } \\
\hline Without pesticide & $191 \mathrm{~b}$ & $106 \mathrm{a}$ & $190 \mathrm{~b}$ & $88 \mathrm{a}$ & $27.45 \mathrm{a}$ & $3,419 \mathrm{~b}$ \\
\hline With pesticide & $210 \mathrm{a}$ & $107 \mathrm{a}$ & $209 \mathrm{a}$ & $89 \mathrm{a}$ & $27.37 \mathrm{a}$ & $3,705 \mathrm{a}$ \\
\hline \multicolumn{7}{|l|}{ Cultivars } \\
\hline BRS Caçula & $241 \mathrm{a}$ & $106 \mathrm{c}$ & $240 \mathrm{a}$ & $88 \mathrm{~b}$ & $27.22 \mathrm{~b}$ & $2,508 \mathrm{c}$ \\
\hline BRS Serra Dourada & $232 \mathrm{a}$ & $100 \mathrm{~d}$ & $230 \mathrm{~b}$ & $91 \mathrm{a}$ & $23.10 \mathrm{c}$ & $3,774 \mathrm{~b}$ \\
\hline BRS Sertaneja & $146 \mathrm{c}$ & $111 \mathrm{a}$ & $144 \mathrm{c}$ & $86 \mathrm{c}$ & $30.95 \mathrm{a}$ & $2,895 \mathrm{c}$ \\
\hline BRS Esmeralda & $197 \mathrm{~b}$ & $107 \mathrm{bc}$ & $196 \mathrm{~b}$ & $88 \mathrm{~b}$ & $27.37 \mathrm{~b}$ & $4,533 \mathrm{a}$ \\
\hline BRS Primavera & $188 \mathrm{~b}$ & $109 \mathrm{ab}$ & $187 \mathrm{~b}$ & $88 \mathrm{~b}$ & $28.41 \mathrm{~b}$ & $4,102 \mathrm{~b}$ \\
\hline Factors & \multicolumn{6}{|c|}{ F p-value } \\
\hline Cultivars (C) & $<0.001$ & $<0.001$ & $<0.001$ & $<0.001$ & $<0.001$ & $<0.001$ \\
\hline Compaction pressure (CP) & 0.0213 & $<0.001$ & 0.0238 & 0.1396 & 0.6580 & $<0.001$ \\
\hline Seed treatment $(\mathrm{ST})$ & 0.0149 & 0.0967 & 0.0151 & 0.1954 & 0.8388 & 0.0022 \\
\hline $\mathrm{N}$ management $(\mathrm{N})$ & 0.7098 & $<0.001$ & 0.6798 & 0.0856 & 0.8203 & 0.0120 \\
\hline $\mathrm{C} \times \mathrm{CP}$ & 0.5651 & 0.0687 & 0.5567 & 0.5700 & 0.5523 & 0.2690 \\
\hline $\mathrm{C} \times \mathrm{ST}$ & 0.7443 & 0.0501 & 0.7401 & 0.1298 & 0.8155 & 0.0169 \\
\hline $\mathrm{C} \times \mathrm{N}$ & 0.7501 & 0.0539 & 0.7744 & 0.1617 & 0.3808 & 0.5492 \\
\hline $\mathrm{CP} \times \mathrm{ST}$ & 0.0506 & 0.0941 & 0.0510 & 0.0506 & 0.1790 & 0.3005 \\
\hline $\mathrm{CP} \times \mathrm{N}$ & 0.4423 & 0.7335 & 0.4554 & 0.0971 & 0.4155 & 0.6932 \\
\hline $\mathrm{TS} \times \mathrm{N}$ & 0.4068 & 0.1500 & 0.4036 & 0.3866 & 0.6686 & 0.0266 \\
\hline $\mathrm{C} \times \mathrm{CP} \times \mathrm{ST}$ & 0.1591 & 0.0999 & 0.1606 & 0.2384 & 0.9476 & 0.2645 \\
\hline $\mathrm{C} \times \mathrm{CP} \times \mathrm{N}$ & 0.9018 & 0.0512 & 0.8978 & 0.9314 & 0.3248 & 0.8676 \\
\hline $\mathrm{CP} \times \mathrm{ST}$ x N & 0.4900 & 0.8674 & 0.5252 & 0.3538 & 0.0558 & 0.1468 \\
\hline $\mathrm{C} \times \mathrm{CP} \times \mathrm{ST} \times \mathrm{N}$ & 0.7876 & 0.5333 & 0.7967 & 0.9596 & 0.7118 & 0.3671 \\
\hline
\end{tabular}

${ }^{1}$ Means followed by the same letter in the column do not differ according to the Tukey's test $(\mathrm{p} \leq 0.05)$. The average cultivar growth duration was 109 days.

Table 2. Effect of interactions between cultivars and seed treatment, and between seed treatment and nitrogen management, in the grain yield of upland rice cultivated under no-tillage system.

\begin{tabular}{|c|c|c|}
\hline \multirow{3}{*}{ Cultivars } & \multicolumn{2}{|c|}{ Seed treatment with pesticide } \\
\hline & without & with \\
\hline & \multicolumn{2}{|c|}{$\mathrm{kg} \mathrm{ha}^{-1}$} \\
\hline BRS Caçula & $2,467 \mathrm{c} \mathrm{A}^{1}$ & $2,548 \mathrm{~d} A$ \\
\hline BRS Serra Dourada & $3,701 \mathrm{~b} \mathrm{~A}$ & 3,848 bc A \\
\hline BRS Sertaneja & $2,430 \mathrm{c} \mathrm{B}$ & $3,359 \mathrm{c} \mathrm{A}$ \\
\hline BRS Esmeralda & 4,443 a A & 4,624 a A \\
\hline \multirow[t]{3}{*}{ BRS Primavera } & $4,056 \mathrm{ab} \mathrm{A}$ & $4,147 \mathrm{ab} \mathrm{A}$ \\
\hline & \multicolumn{2}{|c|}{$\mathrm{N}$ management } \\
\hline & $\mathrm{N}$ at topdressing & $\mathrm{N}$ at sowing \\
\hline Without pesticide & $3,201 \mathrm{~b} \mathrm{~B}$ & 3,637 a A \\
\hline With pesticide & 3,691 a A & 3,719 a A \\
\hline
\end{tabular}

of production (Barbosa et al. 2009). On the other hand, the other genotypes (BRS Caçula, BRS Serra Dourada, BRS Esmeralda and BRS Primavera) were not affected by seed treatment. It is likely that these genotypes are more resistant to termite attack, and the use of insecticide did not increase grain yield. According to Barrigossi et al. (2011), termites show a preference for some rice genotypes.

In NTS, when $\mathrm{N}$ is applied at topdressing, treated seeds produced higher grain yield (Table 2 ). On the other hand, when $\mathrm{N}$ was applied at sowing, there was no pesticide effect on seeds. These results could be due to the better development of rice plants when $\mathrm{N}$ was applied at sowing than at topdressing. Rice plants cultivated under NTS should receive a larger amount of $\mathrm{N}$ at sowing to avoid a lack of this 
nutrient due to bacterial $\mathrm{N}$ fixation (Nascente et al. 2011, 2013a).

Under CTS, there are differences in the number of tillers and number of panicles $\mathrm{m}^{-2}$, and the highest values were achieved when $\mathrm{N}$ was applied at topdressing, 20 days after sowing (Table 3 ). This could happen because, after soil plowing under CTS, more $\mathrm{N}$ could have been lost due to leaching (D'Ándrea et al. 2004, Aranda et al. 2011). According to D'Andréa et al. (2004), nitrate is easily leachable and this leaching is directly related to the volume of water available. In our trial, rainfall was high after sowing (Figure 1). Therefore, the split application of $\mathrm{N}$ probably reduced $\mathrm{N}$ loss and made this nutrient available to the rice plants.

Under CTS, the use of soil compaction in the soil furrow was not effective in increasing grain yield
(Table 3). This is because soil plowing causes soil disintegration and mixes the organic matter and roots of crops in upper soil layers $(0-0.20 \mathrm{~m})$. Therefore, only the "V" wheels with this disintegrated soil increased the contact between seed and soil, and provided good rice plant development, as shown in our results. Under CTS, seed treatment with insecticide increased grain yield for all the cultivars evaluated (Table 3 ).

The BRS Esmeralda genotype was the most productive in NTS (Table 1) and BRS Esmeralda and BRS Primavera were the most productive in CTS (Table 3). According to Moura Neto et al. (2002), Guimarães et al. (2006), Nascente et al. (2011) and Nascente et al. (2013b), producers should observe which genotypes produce more in each soil management, when they grow rice, in order to maximize yield.

Table 3. Number of tillers (NT), plant height (PH), number of panicles $\mathrm{m}^{-2}$ (PAN), spikelet fertility (SF), 1,000-grain weight (MGRAIN) and grain yield (YIELD) of upland rice cultivars under conventional tillage, as a function of $\mathrm{N}$ management, compaction pressure on seed furrow and seed treatment with pesticides.

\begin{tabular}{|c|c|c|c|c|c|c|}
\hline Treatment & NT & $\mathrm{PH}$ & PAN & SF & MGRAIN & YIELD \\
\hline$N$ management & $\mathrm{n}^{0} \mathrm{~m}^{-2}$ & $\mathrm{~cm}$ & $\mathrm{n}^{\mathrm{o}} \mathrm{m}^{-2}$ & $\%$ & $\mathrm{~g}$ & $\mathrm{~kg} \mathrm{ha}^{-1}$ \\
\hline 20 days after sowing & $240 \mathrm{a}^{1}$ & $114 \mathrm{a}$ & $239 \mathrm{a}$ & $88 \mathrm{a}$ & $27.84 \mathrm{a}$ & $4,720 \mathrm{a}$ \\
\hline 1 day after sowing & $225 \mathrm{~b}$ & $114 \mathrm{a}$ & $224 \mathrm{~b}$ & $88 \mathrm{a}$ & $28.09 \mathrm{a}$ & $4,585 \mathrm{a}$ \\
\hline \multicolumn{7}{|l|}{ Compaction pressure } \\
\hline $25 \mathrm{kPa}$ & $233 \mathrm{a}$ & $114 \mathrm{a}$ & $232 \mathrm{a}$ & $88 \mathrm{a}$ & $27.87 \mathrm{a}$ & $4,586 \mathrm{a}$ \\
\hline $126 \mathrm{kPa}$ & $232 \mathrm{a}$ & $115 \mathrm{a}$ & $231 \mathrm{a}$ & $88 \mathrm{a}$ & $28.07 \mathrm{a}$ & $4,718 \mathrm{a}$ \\
\hline \multicolumn{7}{|l|}{ Seed treatment } \\
\hline Without pesticide & $239 a$ & $114 \mathrm{a}$ & $238 \mathrm{a}$ & $88 \mathrm{a}$ & $27.79 \mathrm{~b}$ & $4,569 \mathrm{~b}$ \\
\hline With pesticide & $226 \mathrm{a}$ & $114 \mathrm{a}$ & $225 \mathrm{a}$ & $88 \mathrm{a}$ & $28.14 \mathrm{a}$ & $4,735 \mathrm{a}$ \\
\hline \multicolumn{7}{|l|}{ Cultivars } \\
\hline BRS Caçula & $275 \mathrm{a}$ & $110 \mathrm{c}$ & $274 \mathrm{a}$ & $90 \mathrm{a}$ & $28.10 \mathrm{~b}$ & $3,421 \mathrm{c}$ \\
\hline BRS Serra Dourada & $287 \mathrm{a}$ & $110 \mathrm{c}$ & $285 \mathrm{a}$ & $89 a b$ & $27.73 \mathrm{~b}$ & $4,677 \mathrm{~b}$ \\
\hline BRS Sertaneja & $161 \mathrm{c}$ & $119 \mathrm{a}$ & $160 \mathrm{c}$ & $85 \mathrm{c}$ & $29.41 \mathrm{a}$ & $4,444 \mathrm{~b}$ \\
\hline BRS Esmeralda & $228 \mathrm{~b}$ & $113 \mathrm{~b}$ & $227 \mathrm{~b}$ & $88 \mathrm{~b}$ & $26.27 \mathrm{c}$ & $5,410 \mathrm{a}$ \\
\hline BRS Primavera & $212 b$ & $119 \mathrm{a}$ & $211 \mathrm{~b}$ & $88 \mathrm{~b}$ & $28.33 \mathrm{~b}$ & $5,310 \mathrm{a}$ \\
\hline Factors & \multicolumn{6}{|c|}{ F Probability } \\
\hline Cultivars (C) & $<0.001$ & $<0.001$ & $<0.001$ & $<0.001$ & $<0.001$ & $<0.001$ \\
\hline Compaction pressure (CP) & 0.8989 & 0.0860 & 0.9564 & 0.3209 & 0.2417 & 0.1084 \\
\hline Seed treatment (ST) & 0.0745 & 0.6896 & 0.0759 & 0.3593 & 0.0426 & 0.0542 \\
\hline $\mathrm{N}$ management $(\mathrm{N})$ & 0.0454 & 0.8717 & 0.0452 & 0.8183 & 0.1527 & 0.1005 \\
\hline $\mathrm{C} \times \mathrm{CP}$ & 0.2749 & 0.3590 & 0.2876 & 0.8645 & 0.9448 & 0.2884 \\
\hline $\mathrm{C} \times \mathrm{ST}$ & 0.8543 & 0.0947 & 0.8522 & 0.0773 & 0.8552 & 0.0556 \\
\hline $\mathrm{C} \times \mathrm{N}$ & 0.4209 & 0.0843 & 0.4064 & 0.6852 & 0.6415 & 0.3640 \\
\hline $\mathrm{CP} \times \mathrm{ST}$ & 0.4331 & 0.2136 & 0.4396 & 0.2525 & 0.6155 & 0.1873 \\
\hline $\mathrm{CP} \times \mathrm{N}$ & 0.6320 & 0.3214 & 0.5711 & 0.3593 & 0.2853 & 0.7859 \\
\hline $\mathrm{TS} \times \mathrm{N}$ & 0.6484 & 0.4300 & 0.6640 & 0.7018 & 0.3804 & 0.6989 \\
\hline $\mathrm{C} \times \mathrm{CP} \times \mathrm{ST}$ & 0.4422 & 0.1762 & 0.4547 & 0.4941 & 0.1449 & 0.5687 \\
\hline $\mathrm{C} \times \mathrm{CP} \times \mathrm{N}$ & 0.2786 & 0.8394 & 0.2827 & 0.7921 & 0.9694 & 0.4283 \\
\hline $\mathrm{CP} \times \mathrm{ST} \times \mathrm{N}$ & 0.5995 & 0.1270 & 0.5907 & 0.7594 & 0.1918 & 0.2294 \\
\hline $\mathrm{C} \times \mathrm{CP} \times \mathrm{ST} \times \mathrm{N}$ & 0.9536 & 0.1561 & 0.9567 & 0.4600 & 0.9579 & 0.1396 \\
\hline
\end{tabular}

${ }^{1}$ Means followed by the same letter in the column do not differ according to the Tukey's test $(\mathrm{p} \leq 0.05)$. The average cultivar growth duration was 109 days. 
In Brazil, most farmers cultivate rice when new areas are open or in pasture renovation. In both cases, they use CTS, which may cause serious soil erosion. NTS is a good option for producing upland rice with reduced risks of soil erosion. Our results demonstrate that it is possible to produce upland rice under NTS, however, farmers should consider a number of factors, such as the genotype most adapted to this condition, $\mathrm{N}$ application time and compaction pressure in the seed furrow. By using these practices, farmers will reduce the risk of poor results using NTS and contribute to a sustainable agriculture. Farmers who prefer to use CTS should be careful about avoiding erosion and using practices to reduce this problem, in addition to choose the best cultivar for this system and treat seeds with insecticide.

\section{CONCLUSIONS}

1. Applying $\mathrm{N}$ at sowing instead of at topdressing produces higher grain yield under no-tillage system.

2. Under conventional tillage, the $\mathrm{N}$ application time has no effect on upland rice grain yield. Under no-tillage system, upland rice genotypes show better results with higher compaction pressure in the seed furrow.

3. The BRS Sertaneja had higher grain yield with insecticide seed treatment.

4. Under conventional tillage, insecticide seed treatment increases grain yield for all upland rice genotypes.

5. The BRS Esmeralda genotype was the most productive under no-tillage system and the BRS Esmeralda and BRS Primavera were the most productive under conventional tillage.

\section{REFERENCES}

ARANDA, V. et al. Effect of soil type and management (organic vs. conventional) on soil organic matter quality in olive groves in a semi-arid environment in Sierra Mágina Natural Park (S Spain). Geoderma, Amsterdam, v. 164, n. 1-2, p. 54-63, 2011.

BARBOSA, L. H. A. et al. Produtividade do arroz de terras altas após cultivo de plantas de cobertura no Cerrado goiano. Revista Brasileira de Agroecologia, Cruz Alta, v. 4, n. 2, p. 200-203, 2009.
BARRIGOSSI, J. A. et al. Efeito da compactação de sulco de plantio e de tratamentos de sementes na infestação de cupins em arroz de terras altas, em plantio direto. In: SIMPÓSIO BRASILEIRO DE TERMITOLOGIA, 1., 2011, Anápolis. Anais... Anápolis: Universidade Estadual de Goiás, 2011. 1 CD-ROM.

CHEN, Y.; TESSIER, S.; IRVINE, B. Drill and crop performances as affected by different drill configurations for no-till seeding. Soil and Tillage Research, Amsterdam, v. 77, n. 2, p. 147-155, 2004.

CLAESSEN, M. E. C. Manual de métodos de análise de solo. 2. ed. Rio de Janeiro: Embrapa Solos, 1997.

D'ANDRÉA, A. F. et al. Estoque de carbono e nitrogênio e formas de nitrogênio mineral em um solo submetido a diferentes sistemas de manejo. Pesquisa Agropecuária Brasileira, Brasília, DF, v. 39, n. 2, p. 179-186, 2004.

DOBERMANN, A.; FAIRHURST, T. Rice: nutrient disorders \& nutrient management. Los Baños: IRRI, 2000.

EMPRESA BRASILEIRA DE PESQUISA AGROPECUÁRIA (Embrapa). Centro Nacional de Pesquisa de Solos. Sistema brasileiro de classificação de Solos. 2. ed. Rio de Janeiro: Embrapa Solos, 2006.

FAGERIA, N. K. Nitrogen management in crop production. Boca Raton: CRC Press, 2014.

FAGERIA, N. K.; MOREIRA, A.; COELHO, A. M. Yield and yield components of upland rice as influenced by nitrogen sources. Journal of Plant Nutrition, London, v. 34, n. 3, p. 361-370, 2011.

FAOSTAT. Production: crops. 2014. Available at: <http:// faostat3.fao.org/browse/Q/QC/E >. Acess on: 29 Oct. 2014.

FAROOQ, M. et al. Strategies for producing more rice with less water. Advances in Agronomy, San Diego, v. 101, n. 1, p. 351-388, 2009.

FERREIRA, E. et al. Fatores influenciando o ataque de cupim rizófago em plantio direto de arroz de terras altas. Pesquisa Agropecuária Tropical, Goiânia, v. 37, n. 3, p. 176-181, 2007.

GUIMARÃES, C. M.; STONE, L. F.; CASTRO, E. da M. de. Comportamento de cultivares de arroz de terras altas no sistema plantio direto em duas profundidades de adubação. Bioscience Journal, Uberlândia, v. 22, n. 1, p. 53-59, 2006.

KLUTHCOUSKI, J. et al. Manejo do solo e o rendimento de soja, milho, feijão e arroz em plantio direto. Scientia Agricola, Piracicaba, v. 57, n. 1, p. 97-104, 2000.

MOURA NETO, F. P.; SOARES, A. A.; AIDAR, H. Desempenho de cultivares de arroz de terras altas sob plantio direto e convencional. Ciência e Agrotecnologia, Lavras, v. 26, n. 5, p. 904-910, 2002. 
NASCENTE, A. S. et al. Cultivares de arroz de terras altas afetadas pelo manejo do solo. Revista Brasileira de Ciências Agrárias, Recife, v. 8, n. 3, p. 428-434, 2013 b.

NASCENTE, A. S. et al. Desenvolvimento e produtividade de cultivares de arroz de terras altas em função do manejo do solo. Pesquisa Agropecuária Tropical, Goiânia, v. 41, n. 2, p. 186-192, 2011.

NASCENTE, A. S.; CRUSCIOL, C. A. C. Cover crops and herbicide timing management on soybean yield under notillage system. Pesquisa Agropecuária Brasileira, Brasília, DF, v. 47, n. 2, p. 187-192, 2012.

NASCENTE, A. S.; CRUSCIOL, C. A. C.; COBUCCI, T. The no-tillage system and cover crops: alternatives to increase upland rice yields. European Journal of Agronomy, Amsterdam, v. 45, n. 2, p. 124-131, 2013a.

NASCENTE, A. S.; CRUSCIOL, C. A. C. Cover crops affecting levels of ammonium and nitrate in the soil and upland rice development. Semina: Ciências Agrárias, Londrina, v. 34, n. 5, p. 2189-2202, 2013.

NASCENTE, A. S; LI, Y.; CRUSCIOL, C. A. C. Soil aggregation, organic carbon concentration, and soil bulk density as affected by cover crop species in a no-tillage system. Revista Brasileira de Ciência do Solo, Viçosa, v. 39, n. 3, p. 871-879, 2015.

NAYAR, N. M. Origins and phylogeny of rice. Trivandrum: Elsevier, 2014.

NOKKOUL, R.; WICHITPARP, T. Effect of drought condition on growth, yield and grain quality of upland rice. American Journal of Agricultural and Biological Science, New York, v. 9, n. 3, p. 439-444, 2014.

OLOFINTOYE, J. A.; MABBAYAD, B. B. Weed growth, establishment and yield of an upland rice variety under three tillage systems and four seeding rates. Philippine Agriculturist, Los Baños, v. 63, n. 4, p. 345-352, 1980.

PORTUGAL, J. R. et al. Doses de nitrogênio associadas à inoculação com Azospirilllum brasilense e compactação do solo na linha de semeadura em arroz de terras altas. In: CONGRESSO BRASILEIRO DE ARROZ IRRIGADO, 8., 2013, Santa Maria. Anais... Santa Maria: UFSM, 2013. p. 794-797.

PRASAD, R. Aerobic rice systems. Advances in Agronomy, San Diego, v. 111, n. 12, p. 207-236, 2011.

RADFORD, B. J.; ALLSOPP, P. G. Use of insecticides and a press wheel to control soil insects affecting sorghum and sunflower establishment in southern Queensland. Journal of the Australian Entomological Society, Camberra, v. 26, n. 2, p. 161-167, 1987.

REIS, M. S. et al. Desempenho de cultivares e linhagens de arroz de terras altas sob plantio direto e convencional. Ciência e Agrotecnologia, Lavras, v. 32, n. 5, p. 14351440, 2008.

SANTOS, A. B.; STONE, L. F.; VIEIRA, N. R. A cultura do arroz no Brasil. 2. ed. rev. ampl. Santo Antônio de Goiás: Embrapa Arroz e Feijão, 2006.

SILVA, J. G. Desempenho de semeadora no plantio direto do arroz influenciado por tipos de sulcadores e de compactadores de sulcos. In: CONGRESSO BRASILEIRO DA CADEIA PRODUTIVA DE ARROZ, 2., REUNIÃO NACIONAL DE PESQUISA DE ARROZ, 8., 2006, Brasília, DF. Anais... Santo Antônio de Goiás: Embrapa Arroz e Feijão, 2006. 1 CD-ROM.

SILVA, V. R. Propriedades fisicas e hídricas em solos sob diferentes estados de compactação. 2003. $171 \mathrm{f}$. Tese (Doutorado em Agronomia) - Universidade Federal de Santa Maria, Santa Maria, 2003.

SOARES, A. L. A.; CARRÃO, V. H. Plantio direto de arroz irrigado: uma ponte entre passado e futuro. Porto Alegre: Monsanto, 1993.

SOUSA, D. M. G.; LOBATO, E. Cerrado: correção do solo e adubação. Planaltina: Embrapa Cerrados, 2004. 